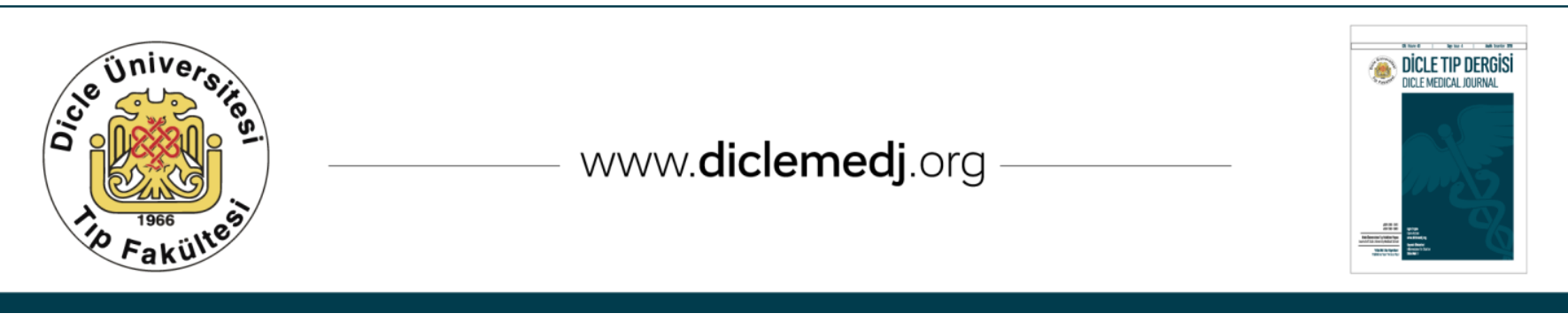

Özgün Araștırma / Original Article

\title{
Treatment of Esophageal Strictures with Savary-Guilliard Bougies
}

\author{
Sehmus Olmez'1, Bünyamin Sarıtaş² ${ }^{2}$ Süleyman Sayar ${ }^{3}$, Banu Kara1 ${ }^{1}$ Burçak Kayhan", \\ Ersan Özaslan ${ }^{5}$, Hasan Tankut Köseoğlu ${ }^{5}$, Emin Altıparmak ${ }^{5}$ \\ 1 Adana Numune Research and Education Hospital, Department of Gastroenterology, Adana, Turkey \\ 2 Özel MedikalPark Elazığ Hospital, Department Of Gastroenterology, Elazı̆̆, Turkey \\ 3 Dr. Ersin Arslan Public Hospital, Deparment of Gastroenterology, Gaziantep, Turkey \\ 4 Karabuk University school of Medicine, Department of Gastroenterology, Karabük, Turkey \\ 5 Ankara Numune Research and Education Hospital, Department of Gastroenterology, Ankara, Turkey
}

Received : 14.09.2016 ; Revised: 09.03.2017 Accepted: 10.03.2017

\begin{abstract}
Objective: Esophageal strictures may be caused by benign or malign disorders. Benign strictures are peptic stricture, Schatzki's ring, esophageal web, and caustic ingestion, post-radiotherapy or post-surgical strictures. Dilatation with Savary-Guilliard bougies (SGD) is the most common endoscopic treatment of choice. In this study, we aimed to investigate the effectiveness of dilatation with Savary-Guilliard Bougies (SGB).

Methods: We retrospectively analyzed the cases treated with SGD in Ankara Numune Education and Research Hospital between October 2005 and June 2011. All the demographic and clinical datas were recorded as well as endoscopic dilatation count and complications.

Results: 73 patients (33(45.2\%) males and 40 (54.8\%) females) involved in the study. Mean age was 55,6 $\pm 15,7(18$ 90) years old. A total of 536 dilatations of 73 patients performed in 169 sessions. Mean sessions of SGD 2,3 $\pm 2.9(1-21)$ and dilatation counts were $7.4 \pm 9.4(1-65)$. The most seen etiologies were esophageal web $(n=14,19.2 \%)$, postradiotherapy $(n=14,19.2 \%)$, anastomotic strictures $(n=11,15.1 \%)$ ingestion of corrosive substances $(n=9,12.3 \%)$ and malign strictures $(n=8,11 \%)$. The most seen benign causes and session counts were compared. Strictures secondary to radiotherapy and ingestion of caustic substances were the most common conditions treated with SGD. A single session was sufficient in strictures caused by esophageal web. No major complications such as perforation, major bleeding or sepsis were observed.

Conclusion: SGD for the treatment of esophageal benign strictures is a safe, cheap, easily performed method without need for fluoroscopy. While treatment of esophageal web is usually treated with a single session, repeated endoscopic dilation sessions are required for the strictures caused by radiotherapy and corrosive ingestion.
\end{abstract}

Keywords: Esophageal Strictures, Dilatation, Savary-Guillard Bougies

DOI: $10.5798 /$ dicletip.319796

Yazışma Adresi / Correspondence: Sehmus Olmez, Adana Numune Research And Education Hospital, Department of Gastroenterology, Adana, Turkey e-mail: drsehmusolmez@gmail.com 


\section{Özofagus Darlıklarının Savary-Guillar Bujileri ile Dilatasyonu}

\section{Özet}

Amaç: Özofagus darlıkları, benign veya malign hastalıklara bağlı olarak gelişebilir. Benign darlıklar; peptik darlık, Schatzki Halkası, özofagus web, kostik madde alımı, radyoterapi sonrası veya cerrahi sonrası gelișen darlıklardır. Savary-Guillard Bujileri ile dilatasyon (SGD) en sık kullanılan endoskopik yöntemdir. Bu çalışmada Savary-Guillard Bujileri (SGB) ile dilatasyon tedavisinin etkinliğini değerlendirmeyi amaçladık.

Yöntemler: Retrospektif olarak Ekim 2005-Haziran 2011 tarihleri arasında Ankara Numune Eğitim ve Araștırma Hastanesinde, SGB ile tedavi edilen hastaları analiz ettik. Tüm demografik ve klinik verileri, endoskopik dilatasyon sayısı ve komplikasyonları kaydettik.

Bulgular: 73 hasta $(33(\% 45,2)$ erkek ve $40(\% 54,8)$ kadın) çalışmaya alındı. Ortalama yaş 55,6 $\pm 15,7(18-90)$ idi. 73 hastaya 169 seansta 536 dilatasyon uygulandı. Ortalama seans sayısı 2,3 $\pm 2.9(1-21)$ ve dilatasyon sayısı da 7.4 $\pm 9.4(1-$ $65)$ idi. En sık görülen etiyoloji web $(n=14, \% 19,2)$, radyoterapi sonrası $(n=14, \% 19,2)$, anastomoz darlı̆g $(\mathrm{n}=11, \% 15,1)$, kostik madde alımı $(\mathrm{n}=9, \% 12,3)$ ve malign darlıklar( $\mathrm{n}=8, \% 11)$ idi. En sık görülen nedenler ve seans sayıları karşılaştırıldı. Radyoterapiyi sekonder ve kostik madde alımına sekonder darlıklar en sık görülen nedenlerdi. . Özofagus web tedavisinde tek seans yeterliydi. Perforasyon, major kanama veya sepsis gibi major komplikasyon görülmedi.

Sonuç; SGB ile özofagus benign darlıklarının tedavisi güvenli, ucuz ve kolayca ve floroskopi olmaksızın uygulanabilen bir yöntemdir. Özofagus webi tek seansta tedavi edilebilmesine rağmen, radyoterapi ve kostik madde alımına bağlı gelişen darlıklarda tekrarlayan dilatasyon işlemlerine gereksinim vardır.

Anahtar kelimeler: Özofagus darlıkları, dilatasyon, Savary-Guillard Bujileri

\section{INTRODUCTION}

Esophageal strictures are a common gastroenterological problem which may be caused by benign or malign disorders. The most common types of benign strictures are peptic stricture, Schatzki's ring, esophageal web, radiotherapy, ingestion of caustic substances and postsurgical anastomotic strictures; malign esophageal strictures may be caused by primary esophageal carcinoma or malignancies that compromise the esophageal lumen by direct invasion or lymph node enlargement ${ }^{1,2}$. The most common symptom of esophageal strictures is dysphagia. Endoscopic methods are widely used for both diagnosis to show underlying benign or malign condition and treatment of strictures. Endoscopic dilatation is the basic treatment option and SGD is the choice of treatment. SGD may be performed with or without fluoroscopy $1,3,4.80-90 \%$ of patients can be treated by SGD or balloon dilatation but these may be insufficient may recur in some of the patients. Some patients may need additional sessions that depend on the etiology and length of the strictures 5 . In recurrent cases may need additional endoscopic treatment options such as incisional methods, stent placement or a combination of these. Rarely, in failure of these methods surgical intervention is used ${ }^{1,6}$.

Serious complications such as perforation even death may occur during endoscopic dilatation of benign esophageal strictures ${ }^{7,8}$. Frequency of complications are increased in dilatations for malignant conditions ${ }^{9}$.

The aim of this study is to evaluate the demographics, etiologies, dilatation sessions, dilatation counts and complications in patients with esophageal stricture that were caused by various benign conditions and treated with SGD.

\section{METHODS}

We retrospectively analyzed the cases treated with SGD in Ankara Numune Education and Research Hospital between October 2005 and June 2011. Age, sex, etiology, dilatation session 
and counts are recorded as well as complications. Additionally, relationship with etiology and dilatation session counts were also analyzed.

After local anesthesia of oropharynx with lidocaine spray patients underwent endoscopic procedures made with Pentax or Fujinon endoscope. If passage of the endoscope failed, esophageal passage imaging was done with barium enema and length of the narrow segment was detected. Patients with high risk of complications underwent procedure under fluoroscopy. A guidewire was inserted under direct visualization with endoscope. Keeping the wire in place, the scope is withdrawn. The stricture is dilated over the guidewire starting with the smallest appropriate bougie. The bougie is moved forward and backward 4-5 times and increase size of bougie depending on existence of hemorrhage and pain. Bougie size is increased gradually (Maximum $15 \mathrm{~mm}$ ). The following dilatation sessions are performed depending on patients' complaints of dysphagia. Patients' age, the etiology of stricture, count of dilatation session, count of total dilatations and complications after the procedure are recorded. The relationship of the most common etiologies and count of dilatation sessions are evaluated statistically.

SPSS for windows version 16 were used for the analysis of data. Categorical variables were expressed as number and percentage, measured variables expressed as mean \pm standard deviation with minimum and maximum. Kruskall Wallis test was used to compare the groups.

\section{RESULTS}

73 patients (33 (45.2\%) male and 40 (54.8\%) female) included in the study. Mean age was $55.6 \pm 15.7$ (18-90) years old. 536 dilatations were performed in 169 dilatation sessions on 73 patients. Mean dilatation sessions were $2,3 \pm 2.9$ (1-21) and bougie dilatation count were $7.4 \pm 9.4$ (1-65)

Etiologies of strictures were esophageal web $(n=14,(19.2 \%))$, secondary to radiotherapy $(n=14,(19.2 \%))$, anastomotic strictures $(n=11$, $15.1 \%$ ) and unknown etiology of various benign conditions except for peptic strictures in different regions of esophagus $(n=12,16.4 \%)$. The distribution of etiologies is shown on table 1.

\begin{tabular}{lcc}
\multicolumn{3}{c}{ Table 1. Etiologies of esophageal strictures in our patients } \\
\hline Etiology & Patients Count (n=73) & \% \\
\hline Web & 14 & 19.2 \\
Secondary to radiotherapy & 14 & 19.2 \\
Anastomotic strictures & 11 & 15.1 \\
Malignancy & 8 & 11 \\
Ingestion of caustic agents & 9 & 12.3 \\
Peptic stricture & 4 & 5.5 \\
Other & 1 & 1.4 \\
Unknown etiology & 12 & 16.4 \\
\hline
\end{tabular}

Patients with esophageal web $(n=14)$, postradiotherapy stricture $(\mathrm{n}=14)$, anastomotic stricture $(n=11)$ and strictures caused by corrosive agents $(n=9)$ are compared by means of sessions' count. Sessions' counts were compared in these four groups and difference between groups were statistically significant $(\mathrm{p}<0,05)$. Session comparison of different etiologies of these groups were shown on table 2 .

\begin{tabular}{lccc}
\multicolumn{4}{l}{ Table 2. Comparison of session's count according to the etiologies } \\
& $\begin{array}{c}\text { Patient number } \\
(\mathrm{n}=48)\end{array}$ & $\begin{array}{c}\text { Session counts } \\
\text { Mean (min-max) }\end{array}$ & $\begin{array}{c}P \\
\text { value }\end{array}$ \\
\hline Web & 14 & $1.21(1-2)$ & \\
Post-radiotherapy & 14 & $4.14(1-21)$ & 0.038 \\
Anastomotic stricture & 11 & $1.82(1-4)$ & \\
Ingestion of caustic agents & 9 & $3.0(1-11)$ & \\
\hline
\end{tabular}


Most of the bougie dilatations performed without fluoroscopy. In some patients with high risk of complications were performed under fluoroscopy. Major complications such as perforations, major bleeding, bacteremia, aspiration were not observed in any patients. Bleeding occurred in five patients without the need for endoscopic intervention and blood transfusion.

\section{DISCUSSION}

Strictures that results in esophageal narrowing are classified as simple or complex strictures. Simple strictures are short, focal, straight type and allows passage of the endoscope. Schatzki's ring, esophageal web, and peptic strictures are simple strictures. And simple strictures are treated with low session counts, effectively and in a very short time. Recurrence of stricture after dilatation is very low. Complex strictures are long, angled, irregular and may cause serious esophageal narrowing, Circular anastomotic strictures, post-radiotherapy and ingestion of caustic substances are the kind of complex strictures. These are hard to treat. Even after endoscopic treatment, dysphagia is not relieved and recurrence is seen more frequently and it takes longer to treat. These are probably related with the thickness of fibrosis in esophagus and the length of narrow segment ${ }^{6,10}$. SGD may be performed in malign strictures effectively and safely. But stent placement is done more frequently in these patients ${ }^{1,11}$. Serious complications such as perforation are seen more frequently in these patients with dilatation ${ }^{12}$. In our study dilatation performed in eight patients (11\%) who had dysphagia due to malignancies. No complications were observed in these patients.

Common causes of esophageal strictures are peptic strictures, post-radiotherapy or ingestion of caustic substances and anastomotic strictures. First line treatment of these strictures are dilatation with bougies or balloon. Success rates of these treatments are $80-90 \%$, but $30-60 \%$ of patients develop dysphagia in long term follow-up and needs dilatation again. Recurrence rate is higher in complex strictures and with the increased number of sessions complication rate will also be higher ${ }^{4,8}$.

There are three types of dilatators: Mercuryweighted bougies (i.e. Maloney bougie dilators), Bougie over guidewire dilators (such as SavaryGuilliard dilators) or TTS (Through-the-scope) balloon dilators. SGB and TTS balloon dilators are the most common treatment modalities and there is no superiority between these modalities. But SGD is cost effective than balloon dilators because of repeated applicability 1 . SGD is the main treatment option especially in dysphagia due to benign conditions ${ }^{1}$.

Serious complications of esophageal dilatation are perforation, massive bleeding, aspiration and bacteremia. Perforation is the most serious complication and may occur $0.1-0.4 \%$ of patients with performed dilatation. Serious complications are seen more in complex strictures such as strictures secondary to radiotherapy or malignancies $9,13-15$. Dilatation under fluoroscopy may decrease the rate of complications, and studies have shown that SGD without fluoroscopy can be done safely and effectively ${ }^{14-16}$. Besides endoscopists' experience is also an important factor for preventing complications, selection of suitable patients and dilatation technique are very important factors as well as clinician's experience ${ }^{14}$.

SGD is accepted as a very effective method for the treatment of esophageal web which causes simple stricture ${ }^{12}$. In our study, web was one of the most seen etiologies of esophageal strictures, and these patients with web required less dilatation sessions than others. Strictures caused by ingestion of corrosive substances and post radiotherapy are complex strictures. These patients need dilatation sessions more than once, recurrence rate and resistance to the treatment are higher than 
others $^{1,2}$. In our study the highest number of dilatation sessions with SGB observed in patients with strictures secondary to radiotherapy and ingestion of corrosive substances. No serious complications were observed in these patients despite the highest dilatation sessions performed on these patients. SGD is the primary therapy of anastomotic strictures and can be performed safely and effectively ${ }^{17}$. Dilation with SGD was performed on 11 patients with strictures secondary to surgical anastomosis safely and effectively. We also observed no complications in these group of patients.

We have performed 536 dilatations on 169 dilatation sessions in 73 patients. Most of the procedures were without the need of fluoroscopy, we observed no serious complications such as perforation, massive bleeding, aspiration and bacteremia. We observed only five bleeding episodes without the need for endoscopic treatment and blood transfusions.

Drawbacks of our study are unknown prior dysphagia score of our patients, no classification of simple or complex strictures before, lack of long term follow up of our patients and also it is done retrospectively.

As a result, SGD is effective, safe, cheap and easily applicable treatment method in patients with dysphagia caused by benign diseases without the need for fluoroscopy. Although SGD is usually effective in only one session in patients with esophageal web, patients with strictures secondary to radiotherapy and ingestion of corrosive substances need more than one session of dilatation therapy.
Abbreviations:

SGB: Savary-Guilliard Bougies

SGD: Dilatation with Savary-Guilliard Bougies

Declaration of Conflicting Interests: The authors declare that they have no conflict of interest.

Financial Disclosure: No financial support was received.

\section{REFERENCES}

1. Siersema PD. Treatment options for esophageal strictures. Nat Clin Pract Gastroenterol Hepatol. 2008; 5: $142-52$.

2. Lew RJ, Kochman ML. A review of endoscopic methods of esophageal dilation. J Clin Gastroenterol. 2002; 35: 117-26.

3. Wang YG, Tio TL, Soehendra N. Endoscopic dilation of esophageal stricture without fluoroscopy is safe and effective. World J Gastroenterol. 2002; 8: 766-8.

4. Canena JM, Liberato MJ, Rio-Tinto RA, et al. A comparison of the temporary placement of 3 different self-expanding stents for the treatment of refractory benign esophageal strictures: a prospective multicentre study. BMC Gastroenterol. 2012; 12 :70.

5. Novais P, Lemme E, Equi C, et al. [Benign strictures of the esophagus: endoscopic approach with SavaryGilliard bougies]. Arq Gastroenterol. 2008; 45: 290-4.

6. van Boeckel PG, Siersema PD. Refractory esophageal strictures: what to do when dilation fails. Curr Treat Options Gastroenterol. 2015; 13: 47-58.

7. Hernandez LV, Jacobson JW, Harris MS. Comparison among the perforation rates of Maloney, balloon, and savary dilation of esophageal strictures. Gastrointest Endosc. 2000; 51: 460-462.

8. Pereira-Lima JC, Ramires RP, Zamin I, Jr., et al. Endoscopic dilation of benign esophageal strictures: report on 1043 procedures. Am J Gastroenterol. 1999; 94: 1497-501.

9. Eisen GM, Baron TH, Dominitz JA, et al. Complications of upper GI endoscopy. Gastrointest Endosc. 2002; 55: 784-793.

10. Altıntaş E TB, Kaçar S, Sezgin O, et al. Benign özofagus darlıklarının etyolojisine göre Savary-Gilliard buji dilatasyonunun etkinliği. Akademik Gastroenteroloji Dergisi. 2003; 2: 15-9. 
11. Pfau PR, Ginsberg GG, Lew RJ, et al. Esophageal dilation for endosonographic evaluation of malignant esophageal strictures is safe and effective. Am J Gastroenterol. 2000; 95: 2813-5.

12. Sreenivas DV, Kumar A, Mannar KV, Babu GR. Results of Savary-Gilliard dilatation in the management of cervical web of esophagus. Hepatogastroenterology. 2002; 49: 188-90.

13. Siddeshi E R KMV, Jaiswal D, Krishna M M. Safety and outcome using endoscopic dilation for benign esophageal stricture without fluoroscopy. J Dig Endosc 2015; 6: 55-8.

14. Standards of Practice C, Egan JV, Baron TH, et al. Esophageal dilation. Gastrointest Endosc. 2006; 63: 755-60.
15. Kabbaj N, Salihoun M, Chaoui Z, et al. Safety and outcome using endoscopic dilatation for benign esophageal stricture without fluoroscopy. World J Gastrointest Pharmacol Ther. 2011; 2: 46-9.

16. Raymondi R, Pereira-Lima JC, Valves A, et al. Endoscopic dilation of benign esophageal strictures without fluoroscopy: experience of 2750 procedures. Hepatogastroenterology. 2008; 55: 1342-8.

17. Hordijk ML, van Hooft JE, Hansen BE, et al. A randomized comparison of electrocautery incision with Savary bougienage for relief of anastomotic gastroesophageal strictures. Gastrointest Endosc. 2009; 70: 849-55. 